\title{
Assessment of management practices of Tswana chickens at North East District of Botswana
}

\author{
John Cassius Moreki ${ }^{\star}$, Kuda Nelson and Wame Boitumelo
}

\author{
Department of Animal Science and Production, Botswana University of Agriculture and Natural Resources, Private Bag \\ 0027, Gaborone, Botswana. \\ ${ }^{\star}$ Corresponding author. Email: jcmoreki@gmail.com
}

Copyright (C) 2016 Moreki et al. This article remains permanently open access under the terms of the Creative Commons Attribution License 4.0, which permits unrestricted use, distribution, and reproduction in any medium, provided the original work is properly cited.

Received 30th June, 2016; Accepted 20th August, 2016

\begin{abstract}
The objective of this study was to document management practices, economic benefits and challenges in indigenous Tswana chicken production in Jackalas No.2, Moroka and Tsamaya villages of North East District of Botswana. Structured questionnaire, oral interviews and field observations were used in collecting data from 50 farmers from the three villages for six successive weeks (i.e., November to December, 2015). All data generated were subjected to descriptive statistics using frequencies, percentages and means. The obtained results showed that $98 \%$ of the poultry rearers were females. Ninety-eight percent $(98 \%)$ of the farmers keep chickens mainly for meat, while two percent (2\%) was for egg consumption. Family chicken production was common in the age group of 21 to 50 years. All the farmers in the study area keepTswana chickens on free-range and grains were provided to supplement what they picked from scavenging. Eighty percent of the farmers in Moroka provide enclosure or confinement at night followed by Jackalas No. $2(70 \%)$ and Tsamaya (55\%). Diseases and parasites contribute to losses in chicken production and $96 \%$ of the rearers used traditional remedies to treat and control diseases with gonde (Aloe sp.) being the most common plant used. In order to increase the benefits of rearing Tswana chickens, the farmers should be trained in general poultry husbandry management and also be encouraged to form associations to assist them in marketing chickens. The obtained results showed that Tswana chickens play an important role in food security at household level of the rural populace.
\end{abstract}

Keywords: Food security, income, indigenous, meat, Tswana chickens.

\section{INTRODUCTION}

Indigenous chickens play important roles in the rural economies of the developing and underdeveloped countries (Padhi, 2016). They are highly important livestock that supply high quality animal protein and income to the rural poor and the marginalized section of the communities (Ayieko et al., 2015; Bekele et al., 2016; Padhi, 2016). They are also important for food security and improved livelihoods (Nyoni and Masika, 2012; Ayieko et al., 2015). Meat and eggs produced from indigenous chickens are tastier and preferred by most consumers compared to that of commercial breeds (CTA, 2007). Referring to the chemical composition, colour and texture of Thai indigenous and broiler chicken muscles, Wattanachant et al. (2004) found that the amino acid profile of the indigenous chicken and broiler muscles were similar while the indigenous chickens were slightly richer in glutamic acid. Glutamic acid is an important participant of brain metabolism and is also a neurotransmitter in a numerous part of the brain synapses and acts through various ionotropic or metabotropic receptors (Kanunnikova, 2012). The other roles of glutamic acid include being endogenic anticancer agent, conjugates to anticancer agents, and derivatives of glutamic acid as possible anticancer agents (Dutta et al., 2013).

Indigenous fowl are not a particular variety but are the result of erratic crosses between local and imported stocks (Guèye, 1998). In Botswana, indigenous chickens are referred to as Tswana chickens. Tswana chickens are comparable to indigenous chickens from other developing countries in terms of growth and overall productivity. Assan (2015) observed that indigenous chickens make a significant contribution to the livelihoods of the poor and offer substantial scope for expansion to 
alleviate poverty, especially in women who comprise $53 \%$ of the human population of North East district (North East District Development Plan 6: 2003-2009). In Botswana, Aganga et al. (2000) reported that Tswana chickens serve as a source of protein to many rural households, since farmers often slaughter the chickens for home consumption. The contribution of family chickens to household food security, poverty alleviation, economic empowerment and HIV/AIDS mitigation in Botswana is scantily documented (Moreki, 2012). The objective of this study was therefore to document management practices, economic benefits and challenges in indigenous Tswana chicken production in Jackalas No.2, Moroka and Tsamaya villages of North East District of Botswana. The main beneficiaries of this study will be the resource-poor farmers through improvement in their livelihoods.

\section{MATERIALS AND METHODS}

\section{Study area}

There are 43 villages in the North East district including Tsamaya, Jackals No. 2 and Moroka (Figure 1). Tsamaya, Jackalas No. 2 and Moroka are about $30 \mathrm{~km}$, $20 \mathrm{~km}$ and $50 \mathrm{~km}$ respectively north-east of the city of Francistown. In addition, these three villages are very close to Zimbabwe border; Tsamaya is about $15 \mathrm{~km}$, Moroka about $10 \mathrm{~km}$, while Jackalas No. 2 is about 2.5 $\mathrm{km}$. It is estimated that Tsamaya, Moroka and Jackalas No. 2 have human populations of 2387, 1692 and 1222, respectively (Central Statistics Office, 2011).

The minimum and maximum temperatures in the district in winter amounted to $5{ }^{\circ} \mathrm{C}$ and $23{ }^{\circ} \mathrm{C}$, while in summer are $17{ }^{\circ} \mathrm{C}$ and $30{ }^{\circ} \mathrm{C}$, respectively. North East district has annual rainfall that averages between 400 $\mathrm{mm}$ (in the south) and $500 \mathrm{~mm}$ (in the north). The rain falls only from October to March, usually in thunderstorms (North East District Development Plan 6: 2003-2009). The vegetation is characterised mainly by tree savanna with Mophane trees (Colophospermum mopane) predominating. Areas inhabited by Mophane trees have poor grass cover. Patchy grass cover is found on most of the communal lands and those parts of the freehold land, which are not overgrazed (North East District Development Plan 6: 2003-2009).

The agricultural sector is an important source of food, income, employment and investment opportunities in rural areas. Therefore, agriculture is the third largest employer in the district. Subsistence farming is practiced in most parts of the district (North East District Development Plan 6: 2003-2009). The district is prone to outbreaks of Foot and Mouth Disease due to its proximity to Zimbabwe where the disease is endemic. This district shares the border with Zimbabwe in the whole eastern side. As a consequence, the Department of Veterinary Services (DVS) continues to monitor the outbreaks and maintain the cordon fence constructed to curb cross border infections. Data supplied by DVS show that the main livestock species reared are cattle (Table 1). According to the DVS report pigs are not reared in the three villages probably due to religious taboos. The Department of Animal Production (2016) showed that Livestock Management and Infrastructure Development (LIMID) Support Programme has provided funds to 20 farmers to purchase Tswana chickens in the study area (Table 2). LIMID is one of the government support programmes that promote the rearing of Tswana chickens and guinea fowl in order to alleviate poverty in the rural areas. Besides data on LIMID beneficiaries no data on family chickens was found implying that the extension service views family poultry to be less valuable compared to other livestock species.

The main crops grown across the district are sorghum, millet, groundnuts and beans mainly because they are able to withstand drought and high temperatures. Most farmers in the North East district cultivate on average 3 to 5 hectares per household and the average age of farmers that participate in farming activities ranges from 50 to 75 years (North East District Development Plan 6: 20032009).

\section{Sampling technique}

Multi-stage cluster sampling with proportional allocation was used to select 50 interviewees across the three villages (Tsamaya - 20; Jackalas No. 2 -15 and Moroka 15).

\section{Data collection}

Data were collected using structured questionnaires and direct observation. The questionnaire was divided into two parts: the first part covered demographic characteristics of the respondents and the second one was on management of Tswana chickens. Questionnaires were administered by approaching the respondents personally at their homes. Questions were read to the interviewees in the local language (i.e., Kalanga) and the responses recorded in English.

\section{Data analysis}

Data were analysed using the statistical functions of Microsoft Excel for descriptive analysis such as frequencies, percentages and means, while the tables and figures were used to summarise the obtained results.

\section{RESULTS AND DISCUSSION}

\section{Demographic characteristics of respondents}

The demographic characteristics of respondents in the 


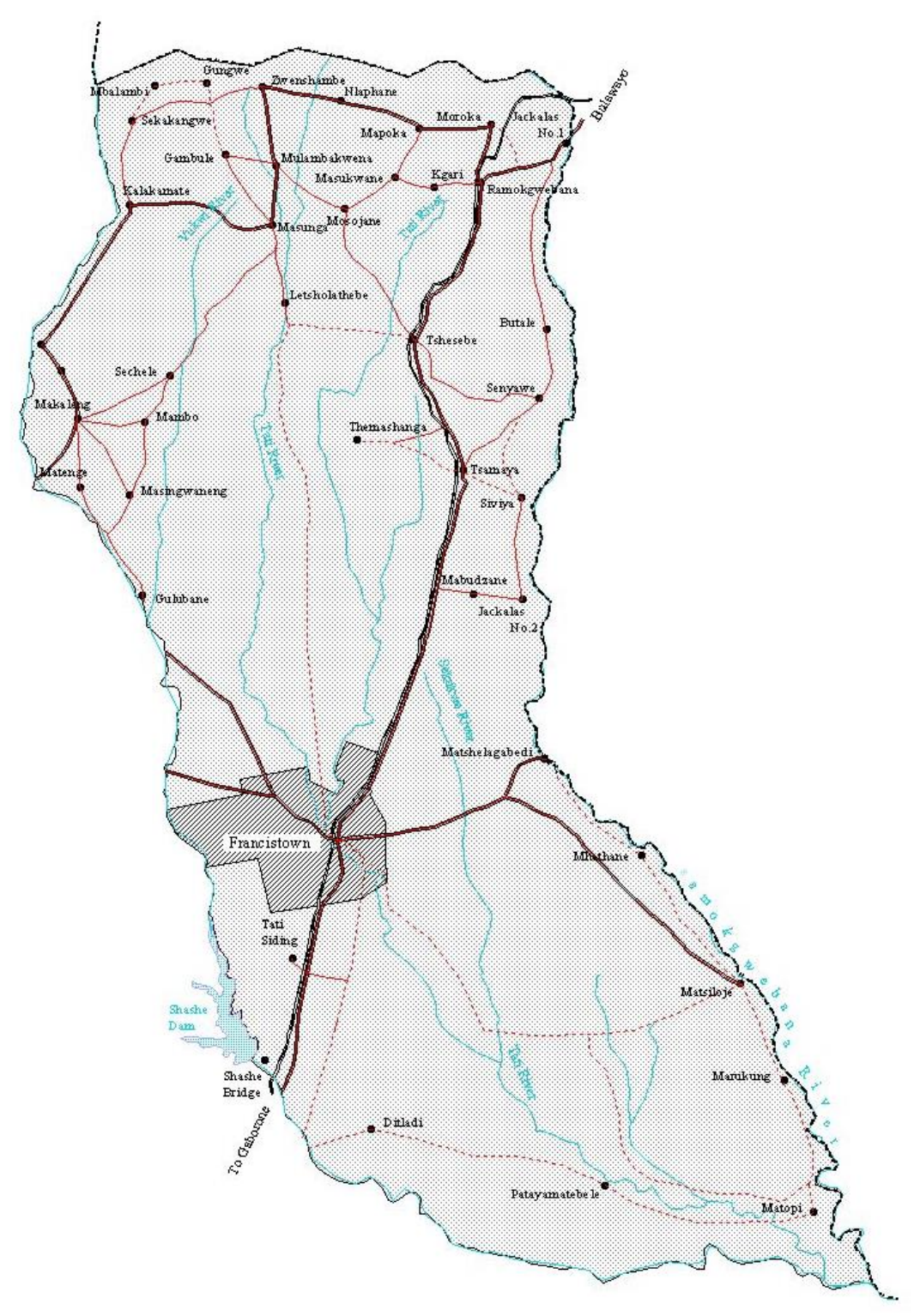

Figure 1. Map of North East District.

Source: North East District Development Plan 6: 2003-2009.

Table 1. populations of cattle, goats and sheep in the study area.

\begin{tabular}{lccc}
\hline Village & Cattle & Goats & Sheep \\
\hline Moroka & 447 & 293 & 12 \\
Tsamaya & 431 & 529 & 51 \\
Jackalas No. 2 & 692 & 608 & 132 \\
\hline
\end{tabular}

Source: Department of Veterinary Services (2015).

three villages are stated in Table 3 . The majority of respondents $(38 \%)$ were aged 21-35 years followed by $36-50$ years $(30 \%)$, indicating that family chicken production is common in the age group of 21 to 50 years.
Females and males constituted $76 \%$ and $24 \%$, respectively. The present result on the participation of women in family chickens could be attributed to the fact that poultry is easy to handle alongside the household chores compared to cattle and small stock (sheep and goats) and/or are affordable to the rural poor. In Kenya, Onyango et al. (2016) found that $65.2 \%$ of females were involved in indigenous chicken rearing compared to $34.8 \%$ for males. Previous study by Aromolaran et al. (2013) showed that people aged 21 to 40 years were more involved in small-scale layer production. Lately, young people in Botswana have developed interest in agriculture probably because of lack of employment opportunities and the existence of government support 
Table 2. Beneficiaries of LIMID Support Programmes in the study area.

\begin{tabular}{lccc}
\hline Village & Number of beneficiaries & Number of chickens & Amount, Pula \\
\hline Tsamaya & 13 & 325 & 128248.25 \\
Jackalas No. & 3 & 75 & 29596.75 \\
Moroka & 4 & 100 & 39463.40 \\
Total & 20 & 500 & 197308.40 \\
\hline
\end{tabular}

Source: Department of Animal Production (2016).

Table 3. Demographic characteristics of chicken farmers in the study area.

\begin{tabular}{lcc}
\hline Parameters & Number of respondents & Percent response \\
\hline Gender & 38 & 76 \\
Female & 12 & 24 \\
Male & & \\
& 6 & 12 \\
Age (years) & 19 & 38 \\
$<20$ & 15 & 30 \\
$21-35$ & 10 & 20 \\
$36-50$ & & \\
$>50$ & 23 & 46 \\
Marital status & 15 & 30 \\
Single & 3 & 6 \\
Married & 8 & 16 \\
Divorced & & \\
Others & & 22 \\
& 11 & 60 \\
Educational level & 30 & 12 \\
Primary & 6 & 6 \\
Secondary & 3 & \\
Tertiary & & \\
None & &
\end{tabular}

programmes such as Youth Development Fund and LIMID.

The majority of the respondents were single (46\%) followed by married (30\%) and others (living together and widowed) (Table 3). Ninety-four percent of the respondents had attended school with the majority (60\%) having secondary school education (Table 3 ) while the study of Aromolaran et al. (2013) reported that all respondents were literate with $77.5 \%$ of them having higher education. The high literacy rate in this study implies that respondents could easily access government assistance support programmes and adopt new technologies with relative ease compared to those that are illiterate. Similarly, Onyango et al. (2016) also reported high literacy rate $(93 \%)$ of indigenous chicken farmers in Kisumu County in Kenya.

Ninety-eight percent of poultry rearers in the present study were women and children while the remainder was males. This result indicates that chickens could play an important role in the empowerment of women. Similarly, Badubi et al. (2006) found that chickens are mainly owned and cared for by women (98\%).

\section{Benefits and reasons for rearing Tswana chickens}

All the respondents in the three villages kept indigenous Tswana chickens which they described as readily available, cheap to obtain and also easy to manage. In addition, Tswana chickens were said to be tolerant to harsh climatic conditions, diseases and parasites compared to commercial broilers and layers. Ninety-eight percent of the respondents said they kept poultry mainly for meat and the remainder for egg consumption. Meat and eggs provided family members with proteins which contribute to a healthy living. Alders and Pym (2009) reported that eggs offer an important source of nutrition containing approximately 315 kilojoules of digestible energy. Eggs are also one of the best sources of quality protein known. In addition, eggs supply an array of vitamins such as $A, B_{12}$, and $K$ (a bone-boosting nutrient that is also involved in blood coagulation) and also provide choline, a B group vitamin that plays a role in brain development and function. Furthermore, Alders (2004) reported that eggs can be stored for several days under village conditions and require very little energy or 
Moreki et al.

Table 4. Number of livestock reared in the study area

\begin{tabular}{lccc}
\hline Category & Tsamaya & Moroka & Jackalas No. 2 \\
\hline Cattle & 112 & 77 & 94 \\
Goats & 268 & 117 & 109 \\
Sheep & 28 & 37 & 40 \\
Donkey & 41 & 25 & 33 \\
Chickens & 336 & 348 & 299 \\
Other poultry & 12 & 5 & 0 \\
\hline
\end{tabular}

time to cook. However, during summer months eggs have a short shelf life due to high ambient temperatures. During this period eggs may not be stored beyond seven days without refrigeration.

The slaughter of birds for family consumption appeared to influence the size of flocks and bird population in the study area. Birds were slaughtered for home consumption in order to reduce feed costs and during disease outbreaks like Newcastle disease (NCD) in order to avoid losses. The slaughter of birds for home consumption ensured the supply of high quality protein to the families which could hardly afford other protein sources such as beef, mutton and goat meat (chevon). Ninety percent of the respondents also mentioned that they slaughtered chickens to honour a guest in the family and also that chickens were given as gifts to children after doing well in their studies.

\section{Livestock reared}

It was observed that chickens (42\%) were kept alongside other livestock species, with $32 \%$ of the farmers rearing goats, cattle (16\%) and other livestock (donkeys, sheep, pigs and guinea fowl) which accounted for $10 \%$ (Table 4). Similarly, the study of Aganga et al. (2000) in five villages in the Gaborone agricultural region of Botswana observed that poultry were kept in conjunction with other types of livestock especially herbivores, with $80 \%$ of the families rearing goats, $50 \%$ with cattle, $40 \%$ with donkeys and $30 \%$ with sheep. The fact that chickens were the main livestock species reared in the current study suggests that chickens play important roles in the sociocultural lives of the rural dwellers. Another reason could be that chickens are easy to manage, require cheaper resources to establish than other livestock species and require less space compared to cattle, sheep and goats. In another study in Zambia, Simainga et al. (2011) reported that the main livestock species reared in Mongu and Kalabo districts were chickens $(50.7 \%)$ followed by cattle $(35.4 \%)$, pigs $(7.76 \%)$ and goats $(6.08 \%)$. Flock size in the current study ranged from 5 to 35 birds per household compared to 15 to 20 chickens/household reported by Badubi et al. (2006) in a study carried out in six agricultural regions of Botswana (i.e., Central, Western, Southern, Francistown, Maun and Gaborone).
In these regions, cattle were preferred livestock species than chickens. This means that the respondents in the present study could afford only chicken raising due to their economic circumstances compared to large livestock. In addition, the small size of North East District $\left(5993 \mathrm{~km}^{2}\right)$ does not support the rearing of livestock such as cattle, sheep and goats in large numbers due to inadequacy of grazing land.

\section{Housing}

Generally, the majority of respondents in this study provided shelter to chickens. Eighty percent of the respondents in Moroka confined poultry at night followed by Jackalas No. 2 (70\%) and Tsamaya (55\%). In agreement with the current results, Tan (2013) observed that village poultry free ranged during the day and were provided with shelter at night to protect them from predators, thus increasing their chances of survival. On average, $15 \%$ of respondents in the present study did not provide shelter to their birds at night, indicating that birds were prone to predation, theft and were exposed to unfavourable weather conditions.

As shown in Figure 2, housing for chickens was basic and was constructed using locally available materials such as old corrugated iron sheets, thatch grass and poles. Generally, housing was of poor structural quality and hence did not last long. Moreki (2006) argued that because of the nature of the housing system, predators, particularly cats caused losses in chicks. In the present study, chicken shelters had earth floors and had roofs that were not rainproof. The fact that shelters had no concrete floors contributed to low production as eggs might be soaked in water during the rainy season leading to poor hatchability. Earth floors made disease control extremely difficult as shelters could not be easily cleaned with water and thereafter disinfected.

In this study, women and children were responsible for locking up chickens at night. This finding is in conformity with Guéye (2005) who reported that women with the help of children are the centre of rural poultry production. Ninety percent of the respondents in the current study mentioned that they hired male persons to construct poultry shelters while the remainder indicated that husbands, brothers and sometimes uncles were involved 

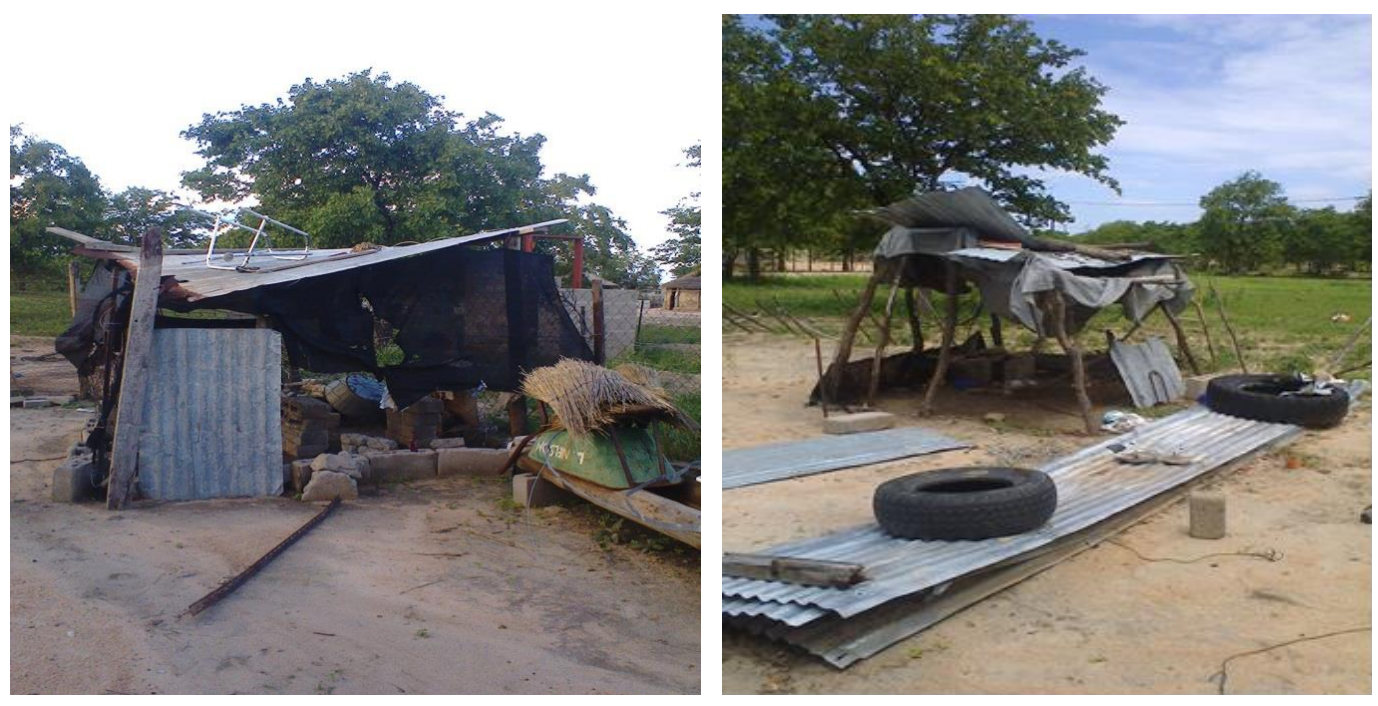

Figure 2. Housing provided to Tswana chickens by the rearers in the study area.

in the construction of shelters. In agreement with this finding, Guéye (2005) observed that though women are the centre of poultry farming, it is the responsibility of men and boys to help women in the construction of poultry shelters.

\section{Feeds and feeding}

All the respondents in this study kept Tswana chickens free-ranged and provided them with supplementary feeds in the form of grains (Figure 3 ) which were usually broadcasted on the ground. This finding is consistent with Addisu et al. (2013) and Bekele et al. (2016) in Ethiopia. Similarly, Moreda et al. (2013) reported that $96 \%$ of farmers provided supplementary feeding to chickens and those chickens of different age groups were fed together. Moreki (2006) also reported that birds spend a large part of the day scavenging for feeds and return home late in the evening for night shelter. Feeds provided to Tswana chickens included kitchen leftovers, grains (sorghum, maize or millet) and mixed fowl feeds (a mixture of crushed maize, sorghum and sunflower seeds) (Figure 3). Grains were mostly used as supplementary feeds at Moroka and Jackalas No. 2 (47\% each). Mixed fowl feeds came second with Jackalas No. 2 having $33 \%$ and Tsamaya $30 \%$, whereas leftovers came last in all the villages. Grains were mostly used as supplementary feeds because they were readily available, especially after a successful harvest season. Due to its high cost, mixed fowl feed was given to chickens in small quantities.

\section{Health management}

\section{Disease control}

In this study, the respondents stated symptoms of diseases which were classified into respiratory problems, diarrhoea, wounds and eye infections. This indicates that the respondents did not know the names of diseases that affected their chickens. It was, however, difficult to diagnose diseases based on the symptoms presented by respondents some symptoms were common to more than one disease. Only four percent of the rearers used veterinary drugs to treat and control diseases while the majority $(96 \%)$ used traditional remedies such as gonde (Aloe sp.) and potassium permanganate. A combination of these remedies was said to be more effective by the rearers.In agreement with the current finding, Moreki (1997) in a previous study in Serowe-Palapye subdistrict found that only two percent of rearers used vaccines compared to $98 \%$ that used traditional remedies. Similarly, Mwobobia et al. (2016) in Kenya found that $80 \%$ of rural farmers used traditional products compared to $57.5 \%$ for peri-urban farmers that used conventional medicines. Only six percent of the rearers in the present study vaccinated their flocks against NCD compared to $94 \%$ that used gonde and potassium permanganate. This result implies that high mortalities due to NCD outbreaks was likely to occur in the study area because of lack of vaccinations. In addition, lack of cold chain and supply of vaccines in large doses coupled with relatively high expense of vaccine could be contributing to low use of vaccines in family chicken production. This calls for the extension service to educate respondents on the importance of disease prevention through vaccinations, as well as, vaccine handling. In agreement with the present result, Bekele et al. (2016) reported that a traditional treatment (ethnoveterinary) was the major treatment used for diseases like NCD by the majority of village chicken owners in Bench Maji Zone of South Western Ethiopia. According to Mwale et al. (2005), ethno veterinary medicine (EVM) is applied in all forms of 


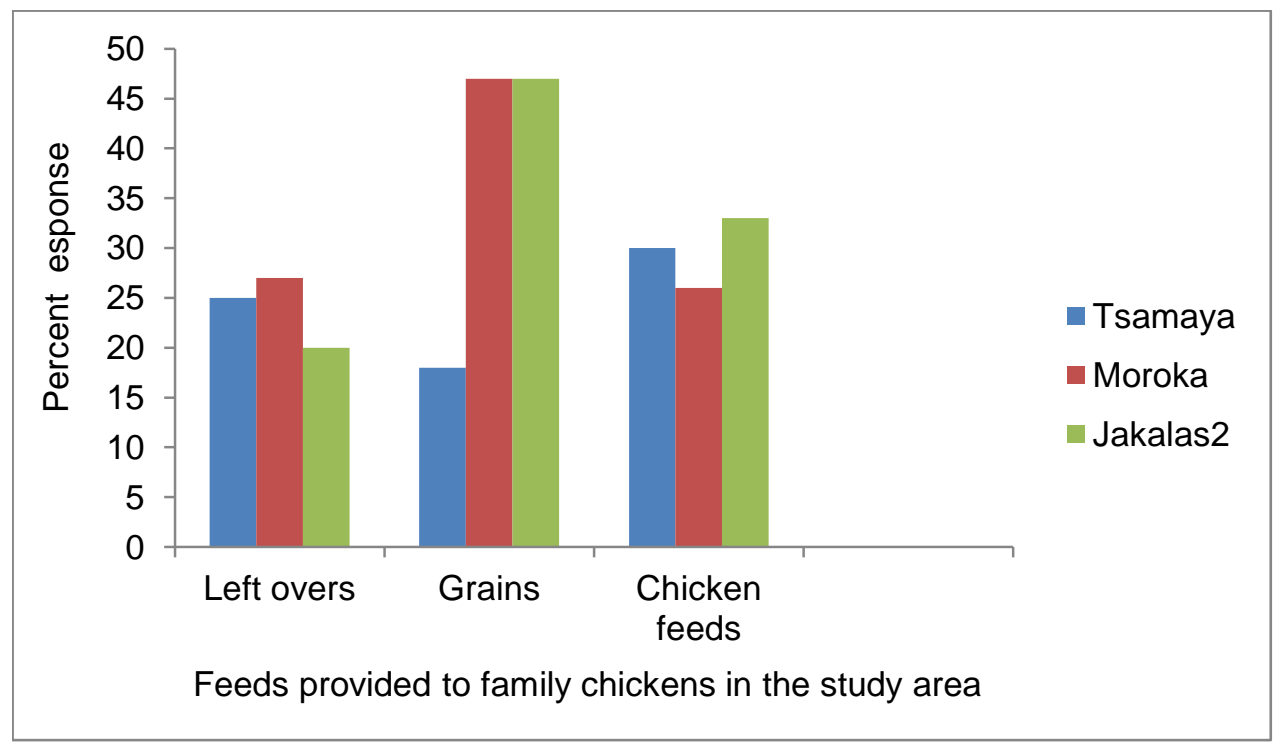

Figure 3. Percentage of farmers that provided supplementary feeds to chickens. https://espace.library.uq.edu.au/view/UQ:176193/wp45.pdf.

livestock, and even to humans especially in the stallholder farming sector of Zimbabwe. In addition, no side effects in the use of various EVM practices have been reported probably explaining why most rural communities have confidence in indigenous health management practices.

Although, different traditional remedies were used to control and treat diseases, $80 \%$ of the respondents used gonde as it was said to be the most effective remedy followed by potassium permanganate (16\%). Mwobobia et al. (2016) also reported Aloe vera, neem tree, pepper and goat milk to be the main traditional products used by chicken farmers. Mwale et al. (2005) attributed the wide use of Aloe sp. to their pharmacological properties and wide distribution. Previous study of Moreki et al. (2010) reported that the leaves of Aloe $s p$. were used in the treatment of diarrhoea, implying that Aloe sp. could be broad spectrum as diarrhoea is a common symptom in most diseases. Mwale et al. (2006) reported that $A$. vera leaf and juice may be used in animals internally or externally implying that it is used for disease and parasite control. Previous study of Mwale et al. (2006) demonstrated that Aloe sp. can be used to control coccidiosis, especially among the resource-poor smallholder farmers.

\section{Parasite control}

The study showed that $70 \%$ of the respondents said their chickens were affected by parasites, $20 \%$ said their chickens were not affected by parasites, whereas the remainder did not indicate whether chickens were or were not affected by parasites. Furthermore, $92 \%$ of the respondents identified the main parasites of family poultry to be tampans, lice, mites and ticks while the remainder could not. These results are in agreement with Moreki et al. (2010). As is the case with diseases, parasite control in this study was predominantly by traditional remedies such as warm or cold water with washing powder, Blue Death chemical (permethrin and carbryl) and used automobile oil. Blue Death is a multi-insect powder used to kill cockroaches, ants and crickets. Similarly, Moreki et al. (2010) reported that dips, Blue Death, wood ash and chemical dusts such as Karbadust (carbryl) were mostly used across the 10 districts of Botswana. Although no respondent in this study mentioned the use of Aloe $s p$. as a traditional remedy against parasites, Moreki et al. (2010) observed that Aloe sp., Jeyes fluid and burning (the area where chickens usually sleep) were some of the traditional methods used against parasites. In Kenya, Okitoi et al. (2007) reported that farmers used Mexican marigold (Tegetes minuta and Tephrosia vogelia) as insect repellents in poultry houses.

\section{Marketing and economic returns}

The respondents sold their chickens live or processed and these were sold throughout the year. Eighty percent of the respondents said they used income from sales to buy school uniforms for children and pay their school fees. The incomes from chicken sales were also used to purchase livestock feeds during dry periods when there is little pasture. In agreement with the current result, Alders and Pym (2009) reported that income from the sale of eggs in South Asia was used to educate children and begin the process of asset accumulation. In addition, 
Table 5. Causes of losses in Tswana chickens in the study area.

\begin{tabular}{lcc}
\hline Category & No. of responses & Percent responses \\
\hline Disease & 33 & 66 \\
Predation & 19 & 38 \\
Parasites & 6 & 12 \\
Theft & 6 & 12 \\
Others & 4 & 8 \\
\hline
\end{tabular}

Alders (2004) pointed out that the sale of poultry products allows investment in other livestock such as goats, cattle, expanded poultry production and other business enterprises (Alders, 2004). Similarly, Gabanakgosi et al. (2013) in Botswana mentioned that chicken proceeds were used to purchase goats. In a related study, Moreki et al. (2010) observed that family chickens can be a stepping stone to rearing small stock and cattle in resource-poor developing countries.

Buyers of chickens were mostly neighbours, friends and passers-by. Cockerels were the first to be sold and a cockerel sold for 60-65 Botswana Pula depending on its body size followed by female adults (50-60 Botswana Pula) and growers (40-50 Botswana Pula). Cockerels were sold to maintain the male to female ratio of 1:5. Only five percent of the respondents sold manure while the rest used it in their gardens. Previous study by Moreki (2001) in 15 villages of Botswana also reported a few farmers using manure to improve fertility status of the soil, indicating that most farmers do not consider manure as a resource but as waste. Eggs were mostly harvested for family consumption to avoid losses and spoilage. In Botswana, Gabanakgosi et al. (2013) reported that eggs were sold cooked or uncooked depending on the consumer's demand, whereas in Ethiopia, chickens and eggs are sold in local and urban markets to traders or directly to consumers depending on the location of the farm dwelling (Badhaso, 2012). Compared to other seasons, egg consumption was high in summer when temperatures and humidity are high; the conditions that contribute to egg spoilage leading to lower hatchability. Moreki (2010) reported lower hatchability rates in summer and spring due to a combination of high temperatures (especially in December and January) and rainfall.

\section{Some major challenges in rearing Tswana chickens}

According to Table 5, diseases accounted for $66 \%$ of losses followed by predation (38\%) parasites and theft $(12 \%)$. In a related study, Moreki et al. (2010) found the major causes of losses in family chickens to be diseases $(36.7 \%)$ followed by diseases and parasites (11.1\%), predation $(8.89 \%)$ and a combination of diseases, parasites and predation (8.89\%). However, in the study that was carried out by Worku et al. (2012), 96.9\% of the respondents identified predators to be the primary production constraints in West Amhara Region of Ethiopia.

The most prevalent disease in this study was NCD which was the major cause of chicken losses. Vaccination against NCD was rarely done mainly because the flock sizes were smaller ( 5 to 35 chickens per household). Moreki (2003) attributed the little use of vaccines by family poultry rearers to the availability of vaccines in large doses (500 and 1000 doses) relative to the size of family chicken flocks which are usually small, for instance, 10 to 20 birds per household.

\section{Conclusions}

From this study, it could be concluded that family chickens play an important role in uplifting the standard of living of the rural households across the three villages. The income from sale of chickens was used to pay school fees for children, and buy food and clothes among others. The use of traditional remedies in managing flock health is wide across the villages. The current findings suggest that family chickens play important roles in food and nutrition security of the rural households; hence increased support from government and other stakeholders would lead to greater benefits.

\section{Recommendation}

Further studies should be carried out to ascertain the effectiveness of traditional remedies in chicken health management with special attention being placed on Aloes $s p$. as a common remedy used by the rearers. In addition, there is need for the extension service to educate farmers in the study area on the importance of disease prevention through vaccinations a well as vaccine handling.

\section{CONFLICT OF INTEREST}

The authors declare that they have no conflict of interest.

\section{ACKNOWLEDGEMENT}

The authors wish to acknowledge the interviewees for sharing their experiences in family chicken rearing. 


\section{REFERENCES}

Addisu, H., Hailu, M., \& Zewdu, W. (2013).Indigenous chicken production system and breeding practice in North Wollo, Amhara Region, Ethiopia. Poultry, Fisheries and Wildlife Sciences, 1, 108.

Aganga, A. A., Omphile, U. J., Malope, P., Motsamai, G. M., \& Motsumi, L. G. (2000). Traditional poultry production and commercial broiler alternatives for small-holder farmers in Botswana. Livestock Research for Rural Development, 12(4), 1-8.

Alders, R. G. (2004). Poultry for profit and pleasure. Diversification Booklet No.3, Agricultural Support Systems Division. Food and AgricultureOrganization of the United Nations, Rome. Retrieved 5th May, 2016. www.researchgate.net/publication/231959582_Village_poultr y_Still

Alders, R. G., \& Pym, R. A. E. (2009). Village poultry: still important to millions, eight thousand years after domestication. World's Poultry Science Journal, 65, 181-190.

Aromolaran Adetayo, K., Ademiluyi, I. O., \& Itebu, O. J. (2013). Challenges of Small Poultry Farms in Layer Production in Ibadan Oyo State Nigeria. Global Journal of Science Frontier Research, 13(2). Retrieved 22 August 2016, from http://www.Irrd.org//rrd12/4/Aga124a.htm.

Ayieko, M. O. D., Bett, E. K., \& Kabuage, L. W. (2015). Analysis of indigenous chicken marketing participation decisions: The case of producers from Makueni County, Kenya. East AfricanAgricultural and Forestry Journal, 81(1), 12-17.

Assan, N. (2015). Cushioning women against gender inequality through promoting indigenous chicken production in sub Saharan Africa.Scientific Journal of Pure and Applied Sciences, 4(6), 119-124.

Badhaso, B. (2012). The status of indigenous chicken production marketing system in Ethiopia, Addis Ababa. Retrieved 05th May, 2016, from http://en.engormix.com/MApoultry/meat-industries/articles/the-status-indigenous-villaget2392/471-p0.htm.

Badubi, S. S., Rakereng, M., \& Marumo, M. (2006). Morphological characteristics and feed resources available for indigenous chickens in Botswana. Livestock Research for Rural Development, 18(1), 205-211.

Bekele, G., Kebede, K., \& Ameha, N. (2016).Study of indigenous chicken production system in Bench Maji Zone, South Western Australia.Global Journal of Science Frontier D Agriculture and Veterinary, 16(2), 21-30.

Central Statistics Office (2011). 2011 Botswana Population and Housing Census. Retrieved 29th June, 2016, from

http://www.cso.gov.bw/media/2011\%20Census\%20_Alphabetic al\%20Index\%20_Population\%20of\%20Villages.pdf

CTA (2007). Improved practices in rearing indigenous chickens. CTA Practical Guide Series, No. 4. Retrieved 22nd June 2016, from http://publications.cta.imt/media/publications/downloads/1379 _full_text.pdf

Department of Animal Production (2016).Ministry of Agriculture. Gaborone, Botswana.

Department of Veterinary Services (2015).Ministry of Agriculture. Gaborone, Botswana.

Dutta, S., Ray, S., \& Nagarajan, K. (2013). Glutamic acid as anticancer agent: An overview. Saudi Pharmaceutical Journal, 21(4), 337-343.

Gabanakgosi, K., Moreki, J. C., Tsopito, C. M., \& Nsoso, S. J. (2013). Impact of family chickens on the livelihoods of people living with HIV and AIDS in four villages of Botswana. Journal World's Poultry Research, 3(2), 43-53.

Guèye, E. F. (1998). Village egg and fowl meat production in Africa. World's Poultry Science Journal, 54, 73-86.

Guèye, E. F. (2005). Gender aspects in family poultry management systems in developing countries.World's Poultry Science Journal, 61, 39-46.

Kanunnikova, N. P. (2012). Role of brain glutamic acid metabolism changes in neurodegenerative pathologies. Journal of Biology and Earth Sciences, 2(1), M1-M10.

Moreda, E., Harrepal, S., Johansson, A., Sisaye, T., \& Sahile, Z. (2013).Characteristics of indigenous chicken production in south west and southern part of Ethiopia.British Poultry Science, 2(3), 25-32.

Moreki, J. C. (1997). Small-scale poultry production systems in Serowe-Palapye sub-district. Master of Applied Science in Agriculture (Doctoral dissertation, Thesis. University of Melbourne, Australia).

Moreki, J. C. (2003). Village poultry and poverty alleviation.In, Community-based managementof animal genetic resources. Proceedings of the workshop heldin Mbabane, Swaziland, 711 May 2001.

Moreki, J. C. (2006). Family poultry production.Poultry Today.Ministry of Agriculture, Gaborone, Botswana.

Moreki, J. C. (2010). Village poultry production in SerowePalapye sub-district of Botswana. Livestock Research for Rural Development, 22(3). Retrieved 22 August 2016, from http://www.Irrd.org/lrrd22/3/more22046.htm.

Moreki, J. C. (2012). Family chickens, poverty alleviation, food security and HIV/AIDS mitigation: The case of BONEPWA+. Journal of AIDS and HIV Research, 4(10), 229-233.

Moreki, J. C., Poroga, B., Dikeme, R., \& Seabo, D. (2010). Ethnoveterinary medicine and health management in poultry in Southern and Western Districts, Botswana. Age, 22(6). Retrieved $22 \quad$ August 2016, from http://www.Irrd.org/Irrd22/6/more22107.htm

Mwale, M., Bhebhe E., Chimoyo, M., \& Halimani, T. E. (2005). Use of herbal plants in poultry health management in the Mushagashe small-scale commercial farming area in Zimbabwe. International Journal of Applied Research in Veterinary Medicine, 3(2), 163-170.

Mwale, M., Bhebhe, E., Chimonyo, M., \& Halimani, T. E. (2006). The in vitro studies on the effect of Aloe vera ((L) Webb. and Berth.) and Aloe spicata (L.F.) on the control of coccidiosis in chickens.International Journal of Applied Research in Veterinary Medicine, 4(2), 128-133.

Mwobobia, R. M., Kanui, T. I., Amwata, D. A., \& Nguku, A. S. (2016). Comparing use of ethnoveterinary products among rural and periurban chicken farmers in Katulani District, Kenya. International Journal of Advanced Research, 4(1), 550-558.

North East District Development Plan 6: 2003-2009. Ministry of Local Government. Gaborone, Botswana. Retrieved 10 August 2016, from http://www.gov.bw/Global/MLG/NORTH\%20EAST.doc

Nyoni, N. M. B., \& Masika, P. J. (2012). Village chicken production practices in the Amatola Basin of the Eastern Cape Province, South Africa. African Journal of Agricultural Research, 7(17), 2647-2652.

Okitoi, L. O., Ondwasy, H. O., Siamba, D. \& Nkurumah, D. (2007). Traditional herbal preparations for indigenous poultry health management in Western Kenya. Livestock Research for Rural Development, 19(5). Retrieved 22 August 2016, from www.Irrd.org/lrrd19/5/okit19072.htm. 
Onyango, R., Obara, J. J., \& Bebe, O. B. (2016). Influence of common interest group membership on productivity of smallholder indigenous chicken enterprise in Kisumu County. International Journal of Science and Research, 5(2), 810-813.

Padhi, M. K. (2016). Importance of Indigenous Breeds of Chicken for Rural Economy and Their Improvements for Higher Production Performance, Scientifica, vol. 2016, Article ID 2604685, 9 pages, 2016. doi:10.1155/2016/2604685

Simainga, S., Moreki, J. C., Banda, F., \& Sakuya, N. (2011). Socio-economic study of family poultry in Mongu and Kalabo Districts of Zambia.Livestock Research for Rural Development, 23(2).

Tan, D. H. Q. (2013). Understanding village poultry through the agricultural household model: a systematic literature review. Second cycle, A2E. Uppsala: SLU, Department of Economics.
Wattanachant, S., Benjakul, S., \& Lesward, D. A. (2004).Composition, colour and texture of Thai indigenous and broiler chicken muscles. Poultry Science, 83, 123-128.

Worku, Z., Melesse, A. \& T/Giorgis, Y. (2012).Assessment of village chicken production system and the performance of local chicken population in West Amhara Region of Ethiopia.Journal of Animal Production Advances, 2(4), 199207. 